\title{
Mastitis İzolatı Staphylococcus aureus Suşlarında Antibiyotik Dirençliliğinin ve Bazı Virülens Genlerinin Araştırılması
}

\author{
Merve Gizem SEZENER $^{1} \quad$ Arzu FINDIK $^{1} \quad$ Volkan Enes ERGÜDEN $^{1} \quad$ Serhan AKGÖZ $^{1}$ \\ Timur GÜLHAN ${ }^{1} \quad$ Alper ÇIFTC $\dot{I}^{1 *}$

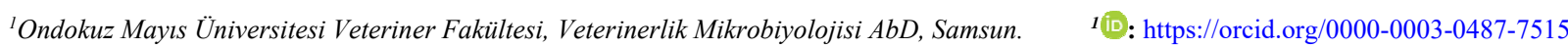
1 D: https://orcid.org/0000-0002-9123-6160 1D: https://orcid.org/0000-0003-2215-2868, 1D: https://orcid.org/0000-0002-5130-7120
\end{abstract} \\ (D): https://orcid.org/0000-0003-4798-1427 $1 *$ (D): https://orcid.org/0000-0001-8370-8677
}

Atıf yapmak için: Sezener, M.G., Fındık, A., Ergüden, V.E., Akgöz, S., Gülhan, T. \& Çiftçi, A. (2019). Mastitis izolatı Staphylococcus aureus suşlarında antibiyotik dirençliliğinin ve bazı virülens genlerinin araştırılması. Anadolu Çev. ve Hay. Dergisi, 4(2), 182 -187.

How to cite: Sezener, M.G., Findik, A., Erguden, V.E., Akgoz, S., Gulhan, T. \& Ciftci A. (2019). The determination of antibiotic resistances and some virulence genes of Staphylococcus aureus isolated from bovine mastitis. Anatolian Env. and Anim. Sciences, 4(2), 182 -187.

Öz: Bu çalışmada mastitis izolatı Staphylococcus aureus suşlarının antibiyotik dirençliliğinin ve bazı virülens genlerinin araştırılması amaçlandı. Çalışma kapsamında 56 adet $S$. aureus izolatı incelendi. İzolatlar fenotipik yöntemlerle ve PCR ile identifiye edildi. İzolatların okzasilin, vankomisin, teikoplanin, trimetoprim-sulfometaksazol, tetrasiklin, penisilin G, sefaperazon ve amoksisilin-klavulonik asite karşı antibiyotik dirençlilikleri Kirby Bauer disk difüzyon yöntemi ile belirlendi. S. aureus izolatlarında virülenste rol oynadığı bilinen coa ve spa genlerinin varlıkları ve polimorfizmleri PCR ile araştırıldı.

İzolatların 7, 5, 4, 5, 4, 3, 5 ve 9 adedinin sırasıyla 8, 7, 6, 5, 4, 3, 2 ve 1 antibiyotiğe karşı dirençli oldukları belirlendi. Ondört izolat ise araştırılan tüm antibiyotiklere duyarlı olarak bulundu. İzolatların 49 adedi 9 farklı profilde coa polimorfizmi gösterdi. Yedi izolatın ise coa geni içermediği belirlendi. İncelenen 56 adet izolatın spa geni içerdiği ve 4 farklı profilde oldukları saptandı.

Sonuç olarak, mastitis kökenli $S$. aureus suşlarında belirlenen antibiyotik direncinin halk sağlığı yönünden bir risk teşkil edebileceği kanısına varıldı..

Anahtar sözcükler: Coa, mastitis, PCR, S. aureus, spa.

\section{The Determination of Antibiotic Resistances and Some Virulence Genes of Staphylococcus aureus Isolated from Bovine Mastitis}

Abstract: This study was aimed to determine the antibacterial resistance profiles and some virulence genes of Staphylococcus aureus isolated from bovine mastitis. A total of $56 \mathrm{~S}$. aureus isolated from bovine mastitis were investigated. The antibacterial resistances of the isolates against oxacillin, vancomycin, teicoplanine, trimetophrim-sulfometaxazole, tetracycline, penicilline G, cefaperazone and amoxicillin-clavulanic acide were determined by Kirby Bauer disc diffusion method.

The 7, 5, 4, 5, 4, 3, 5 and 9 isolates were determined as resistant to 8, 7, 6, 5, 4, 3, 2 and 1 antibiotics, respectively. Fourteen isolates were found as sensitive to all antibiotics. Forty-nine of the isolates showed polymorphism in coa gene and had 9 different coa profiles. Seven isolates did not carry coa gene. All the investigated isolates carried spa gene and showed 4 different profiles.

In conclusion, it was thought that the antibiotic resistant isolates of S. aureus from mastitis may possessed a risk for public health.

Keywords: coa, mastitis, PCR, S. aureus, spa. 


\section{GİRIŞ}

Türkiye, sığır varlığı bakımından önemli bir potansiyele sahip olmakla beraber, elde edilen verim bakımından ise dünya standartlarının altında bulunmaktadır. Türkiye'de süt üretiminde sütçü ineklerin payı her geçen yıl artmaktadır. Türkiye İstatistik Kurumu (TÜİK) verilerine göre 2018 y1lında sütçü ineklerden elde edilen toplam süt miktarı 2010 yılına göre \%61,34 oranında artış göstererek yaklaşık 20 milyon ton'a ulaşmıştır (Anonim, 2019). Sığır mastitisleri süt işletmelerinde azalan süt üretimi, artan tedavi masrafları, itlaf ve ölüm oranları nedeniyle işletmeler ve üreticiler için maliyetli ve multifaktöriyel bir hastalıktır. Mastitis, fiziksel ve kimyasal ajanlarla birlikte çoğunlukla çeşitli infeksiyöz ajanlar tarafından oluşturulmaktadır. Mastitisli inek sütlerinde bakteriyel, viral ve fungal olmak üzere çok farklı mikroorganizma türü izole edilmiştir. En yaygin bakteriyel mastitis nedenleri Escherichia coli, Staphylococcus aureus, Streptococcus agalactiae, Streptococcus dysgalactiae ve Enterococcus faecalis gibi patojenlerdir (Bray \& Shearer, 1994). S.aureus infekte sığırlarda kontagiyöz mastitise neden olan bir meme patojeni iken; E. faecalis, E.coli, S.uberis ve S.dysgalactiae çevresel kaynaklı, altlık, toprak gibi yerlerden fekal kontaminasyon ile infeksiyon oluşturan bakterilerdir.

Stafilokoklar ilk kez 1878'de Robert Koch tanımlanmıştır. Staphylococcus aureus, hem subklinik hem de klinik mastitis vakalarında oldukça fazla bulunmakta olup en çok karşılaşılan kronik mastitis etkenlerinden biridir. Vakalar genellikle subklinik olup ne sütte bir anormallik ne de memede belirlenebilir bir değişiklik yoktur. Bazı sığırlarda özellikle buzağılamadan sonra klinik mastitis olayları patlak verir. Subklinik mastitis vakaları diğer sığırlar için bir infeksiyon kaynağı oluşturabilmekte olup klinik olanlara kıyasla 40-50 kez daha fazla şekillenmesi hastalığın ekonomik önemini artırmaktadır. Günümüzde $S$. aureus nedenli sığır mastitis vakalarının eliminasyonuna yönelik yapılan çalışmalar, yetiştiricilerin birden fazla ve belki de bilinmeyen bazı rezervuarları belirlemedeki yetersizliklerine bağlı olarak tüm infeksiyonları ortaya koyamamaları ve birçok antibiyotik tedavi girişimleri sonucunda ortaya çıkan antibiyotik dirençliliği yüzünden başarılı olamamaktadır (Fox vd., 2001).

Sığırlarda görülen mastitisin şiddeti bakterilerin sahip oldukları virulens faktörlerine ve konak cevabına göre değişmektedir. Son yapılan çalışmalarda, çevresel koşulların değişimi ve infeksiyon sırasında konak-bakteri arasındaki etkileşimler sonucunda virulens özelliklerin ortaya çıkma durumunun da değiştiği belirlenmiştir. $S$. aureus için önemli bir virülens faktörü olan protein A, spa geni tarafından kodlanmakta olup spesifik bakteriyel antijenlere karşı Ig molekülüne bağlanması ve bakteriyi aglütine etmesi gibi özellikleri bakımından immunoloji ve diagnostik laboratuvar teknolojisinde önemli bir reaktiftir (Koneman, 2005). spa geni büyüklük bakımından yüksek derecede değişkenlik göstermekte olup bu varyasyon, genin X- bölgesindeki değişken sayıda 24 bp'lik tekrarlayan sekanslardan kaynaklanmaktadır. $\mathrm{Bu} 24$ bp tekrarlarının sayısı, $S$. aureus'un farklı suşları arasında değişiklik gösterir ve bu nedenle, $S$. aureus'un çeşitli suşları arasındaki genetik çeşitliliği araştırmak ve enfeksiyon kaynağının epidemiyolojik izini sürmek ve virülens fenotiplerindeki farklılıkları karşılaştırmak için moleküler bir araç olarak kullanılabilir (Bhati vd., 2016). Stafilokokların virülensinde rol oynayan koagülaz enzimi de coagulase-reacting faktör ile birleşerek aktifleşmekte ve inaktif olan fibrinojeni fibrine dönüştürerek plazmayı pıhtılaştırmaktadır. Ekstraselluler bir proenzim olan bu faktörün varlığı $S$. aureus icin, patojen olan-olmayan ayrımında önemli bir yere sahiptir. Mikroorganizma fibrin ile kaplanma sonucu opsonizasyondan ve fagositozdan korunabilir ve bu da patojeniteye katkı sağlamış olur. coa geninin 3'-ucu kodlayan bölgesi 81 bp'lik rastgele tekrar serileri içermektedir. Bu seriler, farklı izolatlar arasında sayı ve enzimatik restriksiyon bölgeleri bakımından farklılık göstermektedir. Söz konusu koagulaz gen polimorfizmi, çok sayıda epidemiyolojik çalışmada $S$. aureus'ın identifikasyonu ve karakterizasyonu için kullanılmıştır (Dallal vd., 2016).

Bakterilerin izolasyonu ve identifikasyonu kadar antibiyotik dirençliliğinin de belirlenmesi $S$. aureus nedenli mastitisler için önemli kabul edilmektedir. Özellikle son yıllarda bilinçsiz antibiyotik kullanımının artmasına bağlı olarak, mastitis kökenli bakteriyel izolatlarda antibiyotik direnç sorunları ile karşılaşılmaktadır. $\mathrm{Bu}$ çalışmada, Veteriner Fakültesi Mikrobiyoloji Anabilim Dalı kültür koleksiyonunda bulunan mastitis izolatı $S$. aureus suşlarında antibiyotik dirençliliğinin ve bazı virülens genlerinin araştırılması amaçlanmıştır.

\section{MATERYAL ve METOT}

Bakteri izolatları ve identifikasyonu: Çalışma kapsamında mastitisli sütlerden izole edilmiş olan ve Ondokuz Mayıs Üniversitesi Veteriner Fakültesi Mikrobiyoloji Anabilim Dalı Kültür Koleksiyonu'nda bulunan 56 adet $S$. aureus izolatı incelendi.

Çalışmada kullanılan izolatların fenotipik olarak identifikasyonları gerçekleştirildi (Boynukara vd., 1999; Murray, 2003). İzolatların S. aureus olarak identifikasyonlarının doğrulanması amacıyla $S$. aureus spesifik nuc geni için PCR yapıldı (Zhang vd., 2004). Bu amaçla $25 \mu$ l'lik bir PCR karışımı, DEPC-treated water, $1 \mathrm{X}$ PCR solüsyonu, $2.5 \mathrm{mM} \mathrm{MgCl} 2,0.2 \mathrm{mM}$ her bir dNTP, $1.0 \mathrm{U}$ Taq DNA polimeraz, 0.04 mikromolar primer (nuc 1, GCG ATT GAT GGT GAT ACG GTT; nuc 2, AGC CAA GCC TTG ACG AAC TAA AGC) ve $5 \mu$ template DNA içerecek şekilde oluşturuldu. PCR karışımları $94^{\circ} \mathrm{C}^{\prime} \mathrm{de} 5 \mathrm{dk}$ ön denatürasyonu takiben $94^{\circ} \mathrm{C}$ 'de $1 \mathrm{dk}$ denatürasyon, $50^{\circ} \mathrm{C}$ 'de 
$1 \mathrm{dk}$ primer bağlanma, $72^{\circ} \mathrm{C}$ 'de $2 \mathrm{dk}$ uzama olmak üzere 30 siklus ve $72^{\circ} \mathrm{C}^{\prime} \mathrm{de} 10 \mathrm{dk}$ final uzama koşullarında amplifikasyon işlemine tabi tutuldu. Amplifikasyon ürünleri etidium bromid $(2 \mu \mathrm{g} / \mathrm{ml})$ içeren \%1.5'lik agaroz jel elektroforezi sonrasinda UV transilluminatör ile görüntülendi. Görüntüleme sonrasında nuc geni için 279 bp'lik bantın görülmesi $S$. aureus'un göstergesi olarak kabul edildi.

Virülens Genlerinin Belirlenmesi: Çalışmaya dâhil edilen tüm izolatların koagulaz $(c o a)$ ve protein A $(s p a)$ virülens genleri PCR yöntemi ile belirlendi.

coa gen varlığı ve polimorfizmi Aslantaş vd. (2007)'nın bildirdiği yöntem ile araştırıldı. Bu amaçla COAG2 (5'-CGA GAC CAA GAT TCA ACA AG-3') ve COAG3 (5'- AAA GAA AAC CAC TCA CAT CA-3') primerleri kullanıldı. Bildirilen yönteme göre $25 \square$ '’lik PCR karışımı $5 \mu$ hedef DNA, 1X PCR buffer, 2,5 mM $\mathrm{MgCl}_{2}, 50$ pmol primer çifti, $200 \mu \mathrm{M}$ her bir dNTP ve $1 \mathrm{U}$ Taq polimeraz içerecek şekilde hazırlandı. DNA amplifikasyonu, $95^{\circ} \mathrm{C}$ 'de $2 \mathrm{dk}$ ön denaturasyon; 35 siklus olmak üzere $95^{\circ} \mathrm{C}^{\prime} \mathrm{de} 30 \mathrm{sn}, 60^{\circ} \mathrm{C}$ 'de $2 \mathrm{dk}$ ve $72^{\circ} \mathrm{C}^{\prime} \mathrm{de} 4 \mathrm{dk}$; ve son uzamada $72^{\circ} \mathrm{C}$ 'de $7 \mathrm{dk}$ tutulmak suretiyle gerçekleştirildi. Amplifikasyon ürünleri etidium bromid $(2 \mu \mathrm{g} / \mathrm{ml})$ içeren $\% 2$ 'lik agaroz jel elektroforezi sonrasında UV transilluminatör ile görüntülendi. Görüntüleme sonrasında çeşitli büyüklüklerde bant görülmesi pozitiflik göstergesi olarak kabul edildi. Görüntülenen bant büyüklüklerine göre izolatlar tiplendirildi.

spa gen varlığı ve polimorfizmi Montesinos vd. (2002)'nın bildirdiği yöntem ile araştırıldı. Bu amaçla SPA1 (5'-TCA AGC ACC AAA AGA GGA AGA-3') ve SPA2 (5'-GTT TAA CGA CAT GTA CTC CGT TG-3') primerleri kullanıldı. Bildirilen yönteme göre $25 \square$ l'lik PCR karışımı 1X PCR buffer, $2 \mathrm{mM} \mathrm{MgCl}$, 25 pmol primer çifti, $200 \mu \mathrm{M}$ her bir dNTP, $1.5 \mathrm{U}$ Taq polimeraz ve $5 \mu \mathrm{l}$ hedef DNA, içerecek şekilde hazırlandı. DNA amplifikasyonu, $95^{\circ} \mathrm{C}$ 'de 3 $\mathrm{dk}$ ön denaturasyon; 30 siklus olmak üzere $94^{\circ} \mathrm{C}^{\prime} \mathrm{de} 1 \mathrm{dk}$, $58^{\circ} \mathrm{C}$ 'de $1 \mathrm{dk}$ ve $72^{\circ} \mathrm{C}^{\prime} \mathrm{de} 1 \mathrm{dk}$; ve son uzamada $72^{\circ} \mathrm{C}$ ' de 10 $\mathrm{dk}$ tutulmak suretiyle gerçekleştirildi. Amplifikasyon ürünleri etidium bromid $(2 \mu \mathrm{g} / \mathrm{ml})$ içeren \%3'lik agaroz jel elektroforezi sonrasinda UV transilluminatör ile görüntülendi. Görüntüleme sonrasında çeşitli büyüklüklerde bant görülmesi pozitiflik göstergesi olarak kabul edildi. Görüntülenen bant büyüklüklerine göre izolatlar tiplendirildi.

Antibiyotik Duyarlılı Testleri: Çalışma kapsamında incelenen tüm izolatların antibiyotik duyarlılık testleri Kirby Bauer disk difüzyon tekniği ile CLSI (2018) tarafından önerilen koşullarda gerçekleştirildi. $\mathrm{Bu}$ amaçla standart antibiyotik disklere duyarlılığı belirlenecek bakteri kültüründen birkaç koloni alındı ve tryptic soy broth içerisinde 18 saat $37{ }^{\circ} \mathrm{C}$ 'de inkübasyona bırakıldı. İnkübasyonu takiben kültürün bulanıklığı, McFarland 0.5 standartına göre ayarlandı. Taze sıvı kültürlerden $100 \mu \mathrm{l}$ alınarak Mueller Hinton agar besi yerinin tüm yüzeyini kaplayacak şekilde yayma tekniği ile ekim yapıldı. Standart antibiyotik diskler [okzasilin $(10 \mu \mathrm{g})$, vankomisin $(30 \mu \mathrm{g})$, teikoplanin $(30 \mu \mathrm{g})$, trimetophrim-sulfometaksazol $(25 \mu \mathrm{g})$, tetrasiklin $(30 \mu \mathrm{g})$, penisilin $\mathrm{G}(10 \mu \mathrm{g})$, sefaperazon $(75 \mu \mathrm{g})$, amoksisilin-klavulonik asit $(20 / 10 \mu \mathrm{g})]$ besi yerlerinin üzerine yerleștirildi. Besi yerleri $37{ }^{\circ} \mathrm{C}^{\prime} \mathrm{de} \quad 24$ saat inkübasyona bırakıldı. İnkübasyon süresinin sonunda oluşan zon çapları ölçülerek, standart değerlerle karşılaştırıldı (CLSI, 2013). Sonuçlar duyarlı (S), orta derecede duyarlı (I) ve dirençli (R) olarak değerlendirildi.

\section{BULGULAR ve TARTIŞMA}

İdentifikasyon Sonuçları: Çalışmada kullanılan izolatların fenotipik olarak identifikasyonları sonucunda izolatların tümü $S$. aureus olarak identifiye edildi ve tüm izolatların nuc geni (279 bp) içerdiğinin belirlenmesiyle identifikasyon doğrulandı (Şekil 1).

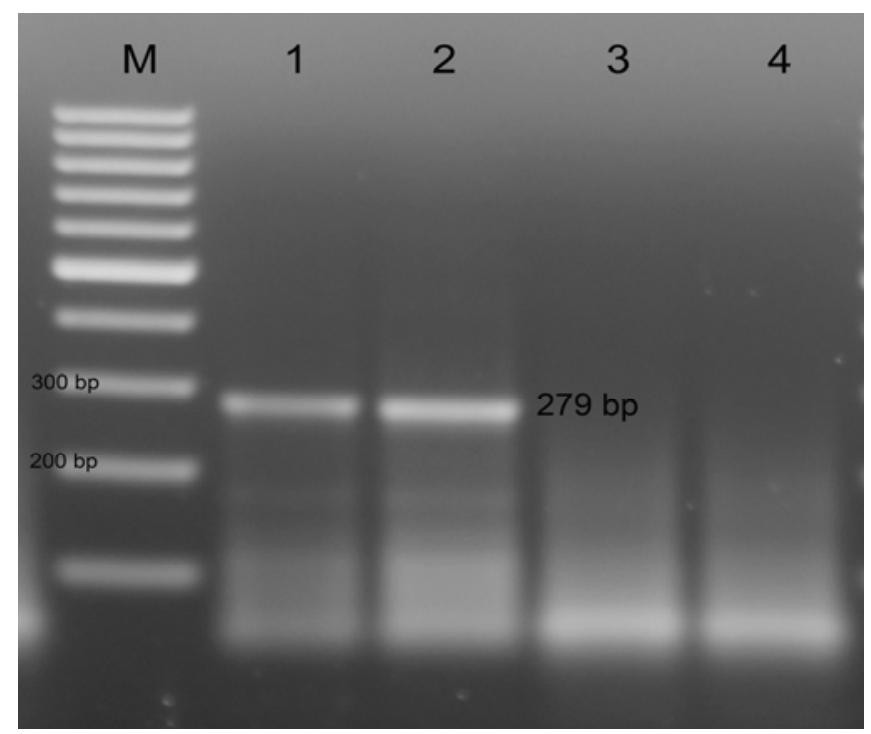

Şekil 1. İncelenen suşların S.aureus yönünden tür düzeyinde değerlendirilmesi için gerçekleştirilen PCR sonucu. M: marker (1001000 bp); 1,2: S. aureus; 3: Escherichia coli; 4; Staphylococcus spp.

Antibiyotik Duyarlılık Testleri: Çalışma kapsamında incelenen tüm izolatların okzasilin $(10 \mu \mathrm{g})$, vankomisin $(30 \mu \mathrm{g})$, teikoplanin $(30 \mu \mathrm{g})$, trimetophrimsulfometaksazol $(25 \mu \mathrm{g})$, tetrasiklin $(30 \mu \mathrm{g})$, penisilin $\mathrm{G}(10$ $\mu \mathrm{g})$, sefaperazon $(75 \mu \mathrm{g})$, amoksisilin-klavulonik asit $(20 / 10$ $\mu \mathrm{g})$ 'e karşı antibiyotik duyarlılık test sonuçları ve direnç profilleri Tablo 1 ve 2 'de gösterilmiştir.

Tablo 1. S. aureus izolatlarının antibiyotik duyarlılık profilleri.

\begin{tabular}{ccccccccc}
\hline Hassasiyet & VA & TEC & OX & SXT & TE & PEN-G & CEP & AMC \\
\hline R & 13 & 14 & 21 & 10 & 16 & 28 & 25 & 26 \\
I & 0 & 5 & 4 & 4 & 7 & 0 & 11 & 0 \\
S & 43 & 37 & 31 & 42 & 33 & 28 & 20 & 30
\end{tabular}

S: duyarlı; I: orta derecede duyarlı; R: dirençli. VA: vankomisin; TEC: teikoplanin OX: okzasilin; SXT: trimetoprim-sulfometaksazol; TE: tetrasiklin; PEN-G: penisilin G; CEP: sefaperazon; AMC: amoksisilin/klavulanik asit

Virülens Genlerinin Belirlenmesi: Çalışmaya dâhil edilen tüm $S$. aureus izolatların koagulaz ( $c o a)$ ve protein A (spa) virülens genleri PCR yöntemi ile belirlendi. 
Tablo 2. İzolatların çoklu antibiyotik direnç profilleri.

\begin{tabular}{ccc}
\hline Direnç saptanan & \multicolumn{2}{c}{ S. aureus } \\
\cline { 2 - 3 } antibiyotik sayısı & n & \% \\
\hline 8 & 7 & 12,50 \\
7 & 5 & 8,93 \\
6 & 4 & 7,14 \\
5 & 5 & 8,93 \\
4 & 4 & 7,14 \\
3 & 3 & 5,35 \\
2 & 5 & 8,93 \\
1 & 9 & 16,08 \\
0 & 14 & 25,00 \\
\hline
\end{tabular}

coa gen varlığı ve polimorfizminin saptanması için yapılan PCR sonucunda 39 adet izolat coa geni yönünden pozitif bulundu. coa pozitif bulunan izolatların göstermiş oldukları bant profilleri Şekil 2 ve Tablo 3 'te gösterilmiştir.

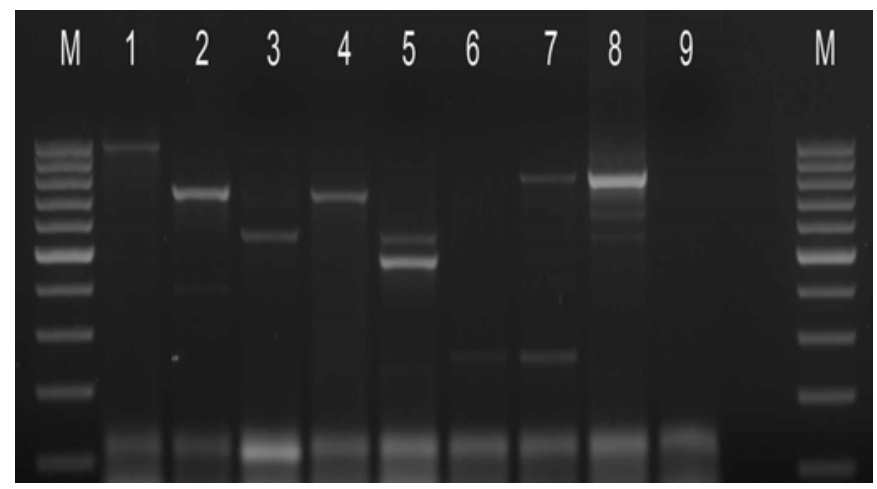

Şekil 2. İncelenen S. aureus izolatlarının coa polimorfizm profilleri.

Tablo 3. S. aureus izolatların coa polimorfizm profilleri

\begin{tabular}{ccc}
\hline coa grup & Bant büyüklüğ̈̈ (bp) & İzolat sayısı \\
\hline 1 & 950 & 2 \\
2 & 800 ve 400 & 3 \\
3 & 550 & 8 \\
4 & 800 & 5 \\
5 & 550 ve 500 & 6 \\
6 & 820 ve 250 & 4 \\
7 & 250 & 5 \\
8 & 820,620 ve 580 & 3 \\
9 & 120 & 13 \\
10 & negatif & 7 \\
\hline
\end{tabular}

Bu çalışmada, spa gen varlığı ve polimorfizmi yapılan PCR sonucunda 47 adet izolat spa geni yönünden pozitif bulundu. spa pozitif bulunan izolatların göstermiş oldukları bant profilleri Şekil 3 ve Tablo 4'te gösterilmiştir.

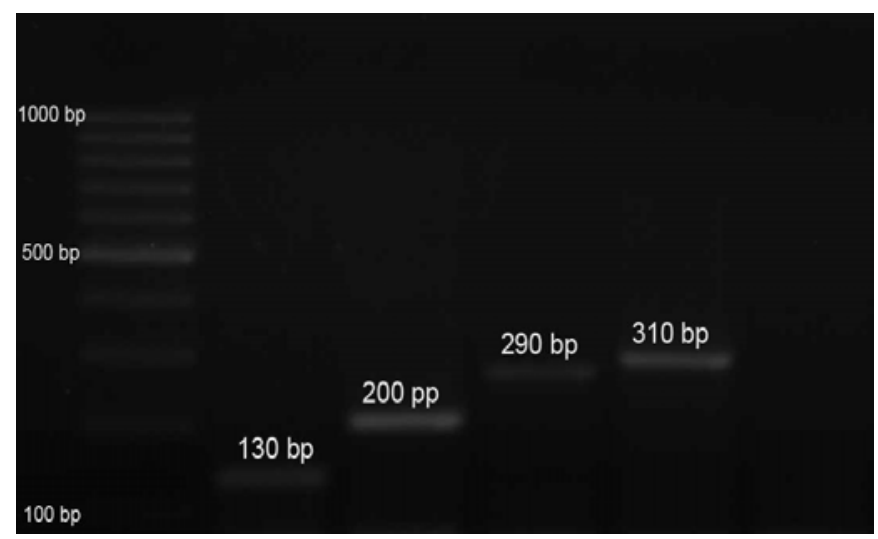

Şekil 3. İncelenen $S$. aureus izolatlarının spa polimorfizm profilleri.
Tablo 4. S. aureus izolatların spa polimorfizm profilleri.

\begin{tabular}{ccc}
\hline spa grup & Bant büyüklüğ̈̈ (bp) & İzolat sayısı \\
\hline 1 & 130 & 14 \\
2 & 200 & 16 \\
3 & 290 & 9 \\
4 & 310 & 17 \\
\hline
\end{tabular}

\section{SONUÇ ve TARTIŞMA}

Sığır mastitisleri süt işletmelerinde azalan süt üretimi, artan tedavi masrafları, itlaf ve ölüm oranları nedeniyle işletmeler ve üreticiler için maliyetli ve multifaktöriyel bir hastalıktır. Mastitis, fiziksel ve kimyasal ajanlarla birlikte çoğunlukla çeşitli infeksiyöz ajanlar tarafından oluşturulmaktadır. S. aureus, sığırlarda kontagiyöz infeksiyona neden olan meme patojenlerinden bir tanesidir. Stafilokokların virülensinde rol oynayan birçok enzim bulunmaktadır. Koagulaz enzimi fibrinojeni fibrine dönüştürerek plazmayı pıhtılaştıran ekstraselüler bir proenzimdir. S. aureus için patojenite kriteri olarak kabul edilen bu enzimin tespiti, patojen olan stafilokokların ayrımı amacıyla rutin olarak kullanılmaktadır. Koagulaz enziminin sentezlenmesi coa geninin varlığına bağlıdır ve çalışmada bu amaçla $S$. aureus izolatlarında coa gen varlığı ile beraber gendeki polimorfizm araştırıldı. coa gen varlığı ve polimorfizminin saptanması için yapılan PCR sonucunda 49 adet izolat coa geni yönünden pozitif, geri kalan 7 adet izolat ise negatif bulundu. coa pozitif bulunan izolatlar, söz konusu gen yönünden sahip oldukları polimorfizm sonucunda sergiledikleri bant profillerine göre gruplandırıldı. PCR sonucunda 9 adet profil belirlendi. İzolatların 7 tanesi coa geni içermemekte iken, 2 izolat 950 bp büyüklüğünde bant meydana getirdi. Üç adet izolat 800 ve 400 bp olmak üzere 2 bant, 8 adet izolat 550 bp'lik tek bant, 5 izolat 800 bp'lik tek bant, 6 adet izolat 550 ve 500 bp'lik 2 bant, 4 adet izolat 820 ve 250 bp'lik 2 bant, 5 adet izolat 250 bp'lik tek bant, 13 adet izolat 120 bp'lik tek bant ve 3 adet izolat ta 820,620 ve 580 bp büyüklüğünde 3 bant oluşturdu. Çiftci vd. (2009) tarafından yapılan bir çalışmada 47 adet koyun mastitis kökenli S.aureus izolatı coa gen varlıkları ve bant büyüklükleri açısından incelenmiş ve izolatları 8 farklı coa gen grubuna ayırmışlardır. Çalışmada izolatların \%42,56'sının 780 bp'lik bant oluşturduğu bildirilmiştir. Scherrer vd. (2004) koyun sütlerinden izole ettikleri 31 adet S. aureus izolatının \%80.6 oranında 820 bp'lik bant oluşturduğunu saptamışlardır. Diğer bir çalışmada da sığır kökenli S. aureus izolatlarında en fazla 580 bp'lik bant görüldüğü bildirilmiştir (Nagase vd., 2002). Su vd. (30), çalışmalarda belirlenen farklı sonuçların bölgesel ve ülkesel farklılıklardan kaynaklandığını belirtmişlerdir. Elde edilen sonuçlar mastitis izolatı bakterilerde coa geni yönünden polimorfizmlerin olduğunu ve bunun da mastitis izolatı $S$. aureus'lardaki bölgesel çeşitliliği gösterdi.

$S$. aureus'un kolonizasyon süreci, konak hücre yüzeyine tutunması ile başlamakta ve bu tutunma bakterinin içerdiği adhezinler aracılığı ile gerçekleşmektedir. $S$. 
aureus'un içerdiği adhezinlerinin büyük bir bölümü hücre peptidoglikanlarında bulunan ve Protein A olarak adlandırılan proteinlerdir. Protein A spesifik bakteriyel antijenlere karşı Ig molekülüne bağlanması ve bakteriyi aglütine etmesi gibi özellikleri bakımından immunoloji ve diagnostik laboratuvar teknolojisinde önemli bir reaktif olarak kullanılmaktadır. Protein A'nın sentezinden sorumlu gen spa genidir. Çalışma kapsamında $S$. aureus olarak identifiye edilen izolatların $s p a$ gen varlığı ve polimorfizmi araştırıldı ve 56 adet izolat spa geni yönünden pozitif bulundu. spa genini taşıdığı tespit edilen izolatların farklı büyüklüklerde bant oluşturduğu ve dolayısıyla 4 farklı grupta olmak üzere polimorfizm gösterdikleri belirlendi. İzolatların 14 adetinin 130 bp, 16 adetinin 200 bp, 9 adetinin 290 bp ve 17 adetinin ise 310 bp büyüklüğünde bant olușturdukları görüldü. spa geninin $\mathrm{X}$ bölgesi 24 bp'lik tekrarlar içermektedir ve bu tekrarlardaki farklılıklara göre de $S$. aureus suşları spa geni yönünden tiplendirilebilmektedir (Frenay vd., 1994; Hallin vd., 2007). spa X-bölgesindeki bu farklılıklar suşların yayılma ve epidemik potansiyelini göstermektedir. Buna göre, tekrar sayısının fazlalığı, suşun epidemik kapasitesinin fazla olmasını sağlamaktadır. Daha uzun X bölgesi, protein-A'nın Fc bağlayıcı bölgesinin daha iyi ortaya çıkmasıyla sonuçlanır. Böylece yüzeye kolonizasyonu kolaylaştırır ve salgına neden olan fenotiplerin ortaya çıkmasına katkıda bulunur (Frenay vd., 1994). Yapılan bir çalışmada (Montesinos vd., 2002), epidemik MRSA suşları incelenmiş ve epidemik suşların daha fazla tekrar içerdiği bildirilmiştir. Çiftci vd. (2009) tarafından yapılan bir çalışmada da epidemik karakterdeki mastitis kökenli suşların 11 tekrar içerdiği belirlenmiştir. Elde edilen bulgular mastitis izolatı $S$. aureus'ların tümünün spa genini taşıdığını, ancak gen yönünden polimorfizmlerin olduğunu gösterdi. Ayrıca çalışmada belirlenen bant büyüklüklerinin de fazla olmaması yani tekrar sayısının az olması da, suşların non-epidemik karakterde olduğunu gösterdi.

Patojen bakteriler tarafından oluşturulan infeksiyonların tedavisinde kullanılan etkili ajanların keşfi modern tıbbın en önemli gelişmelerinden birisi olarak kabul edilmektedir. Günümüzden 2500 yıl önce Çinliler küflenmiş soya fasulyesinin çeşitli cilt enfeksiyonlarındaki tedavi edici etkisini kullanmışlar ve çok eski tarihlerden beri bitkilerden yapılmış ilaçlarla yüzeyel ve sistemik enfeksiyonları tedavi etmeye çalışmışlardır. Modern kimyasal terapi çağı sülfonamidlerin keşfi ve klinik kullanıma girmesiyle başlamıştır. Penisilinin keşfi ve tedavi amaçlı kullanılmaya başlanmasıyla birlikte, stafilokkokal enfeksiyonlara bağlı mortalite oranı hızla azalma göstermiştir. Ancak kısa bir süre sonra, $S$. aureus suşları penisilinaz enzimi üretmeye başlayarak penisiline direnç geliştirmiş ve bu dirençli suşlar hızla yayılmıştır. 1950'lerin sonlarında suşların yaklaşık \%50'si penisiline dirençli hale gelmiştir. Aynı tarihlerde tetrasiklin, kloramfenikol ve eritromisine karşı çoklu direnç gösteren S. aureus suşları bildirilmiştir. İlk semisentetik penisilinaza dirençli antimikrobiyal ajan olan metisilinin klinik kullanıma girmesinden 2 yıl sonra metisiline dirençli S. aureus (MRSA) izolatları İngiltere'den bildirilmiş (Jevons, 1961) ve sonradan 1960 'l 1 y 1 llarda Avrupa'da ve 1970 'li yıllarda ABD'de bir problem haline gelmiştir (Hartstein vd., 1986). Antibiyotiklere çoklu direnç gösteren MRSA suşları 1980'lerin sonlarında ve 1990 'l 1 yllarda tüm dünyaya yayılmıştır (Schmitz vd., 1997). ABD'de MRSA izolatlarının oran1 1975 'te $\% 2$ iken, 1996 'da \%35'e yükselmiștir. Japonya'da 1992-1993 yıllarında çeșitli coğrafik bölgelerdeki hastalardan izole edilen yaklaşık 7000 suşun analizi, $S$. aureus izolatlarının \%60'ının metisiline dirençli olduğunu göstermiştir (Hashimoto vd., 1994). MRSA halen tüm dünyada çeșitli büyüklüklerdeki hastanelerde en sik rastlanan nozokomiyal patojenler arasındadır. Çalıșmada incelenen 56 adet $S$. aureus izolatının \%23,21, \%33,93, \%44,64, \%25,00, $\% 41,07, \% 50,00, \% 64,29, \% 64,29$ ve $\% 46,43$ 'ünün sirasiyla vankomisin, teikoplanin, okzasilin, trimetophrimsulfometaksazol, tetrasiklin, penisilin G, sefaperazon ve amoksisilin-klavulonik asite dirençli olduğu belirlendi. İzolatların $\% 12,50, \% 8,93, \% 7,14, \% 8,93, \% 7,14, \% 5,35$, $\% 8,93$ ve $\% 16,08$ oranında sirasiyla $8,7,6,5,4,3,2$ ve 1 antibiyotiğe karşı dirençli olduğu belirlendi. İzolatların $\% 25,00$ 'inin de test edilen antibiyotiklere duyarlı olduğu saptandi.

Subklinik mastitis vakaları diğer sığırlar için bir infeksiyon kaynağı oluşturabilmekte olup klinik olanlara kıyasla 40-50 kez daha fazla şekillenmesi hastalığın ekonomik önemini artırmaktadır. Günümüzde $S$. aureus nedenli sığır mastitis vakalarının elimine edilmesine yönelik yapılan çalışmalar yetiştiricilerin birden fazla ve belki de bilinmeyen bazı rezervuarları belirlemedeki yetersizliklerine bağlı olarak tüm infeksiyonları ortaya koyamamaları ve birçok antibiyotik tedavi girişimleri sonucunda ortaya çıkan antibiyotik dirençliliği yüzünden başarılı olamamaktadır. Sonuç olarak çoklu antibiyotik direnci nedeniyle mastitis kökenli $S$. aureus'ların hem hayvanın tedavisi hem de halk sağlığı açısından bir risk teşkil edebileceği kanısına varıldı.

\section{KAYNAKLAR}

Anonim (2019). Türkiye İstatistik Kurumu Hayvancllık Istatistikleri.

http://www.tuik.gov.tr/PreTablo.do?alt_id=1002 [Erişim Tarihi: 29.05.2019].

Aslantaş, Ö., Demir, C. \& Türütoğlu, H. (2007). Coagulase gene polymorphism of Staphylococcus aureus isolated from subclinical bovine mastitis. Turkish Journal of Veterinary and Animal Science, 31, 1-5.

Bhati, T., Nathawat, P., Sharma, S.K., Yadav, R., Bishnoi, J. \& Kataria, A.K. (2016). Polymorphism in spa gene of Staphylococcus aureus from bovine subclinical mastitis. Veterinary World, 9(4), 421424. 
Boynukara, B., Gürtürk, G. \& Gülhan, T. (1999). Comparison of latex agglutination tests with protein a, clumping factor and coagulase tests for identification of staphylococci isolated from avian. Eastern Journal of Medicine, 4, 58-60.

Bray, D.R. \& Shearer, J.K. (1994). Milking machine and mastitis control handbook. University of Florida, Cooperative Extension Service, Institute of Food and Agricultural Sciences. Circular. p:1136.

Clinical Laboratory Standards Institute (2018). Performance Standards for Antimicrobial Susceptibility Testing, 28 ${ }^{\text {th }}$ edition: Informational Supplement. CLSI document M100-S28. Clinical and Laboratory Standards Institute, Wayne, PA, USA.

Ciftci, A., Onuk, E.E., Fındık, A., Yıldırım, T. \& Sogut, M.U. (2009). Molecular typing of Staphylococcus aureus strains from ovine mastitis by pulsed-field gel electrophoresis and polymerase chain reaction. Journal of Veterinary Diagnostic Investigations, 21(6), 849-853.

Dallal, M.M.S., Khoramizadeh, M.R., Amiri, S.A., Yaraghi, A.A.S. \& Fard, R.M.N. (2016). Coagulase gene polymorphism of Staphylococcus aureus isolates:A study on dairy food products and other foods in Tehran,Iran. Food Science and Human Wellness, 5, 186-190.

Fox, L.K., Bayles, K.W. \& Bohach, G.A. (2001). Staphylococcus aureus Mastitis. In: Staphylococcus aureus Infection and Disease, ed. Honeyman, A.L., Friedman, H. And Bendinelli, M., Kluwer Academic /Plenum Publishers, New York, pp. 271-293.

Frenay, H.M.E., Theelen, J.P.G. \& Schouls, L.M. (1994). Discrimination of epidemic and nonepidemic methicillin-resistant Staphylococcus aureus strains on the basis of protein A gene polymorphism. Journal of Clinical Microbiology, 32, 846-847.

Hallin, M., Deplano, A. \& Denis, O. (2007). Validation of pulsed-field gel electrophoresis and spa typing for long-term, nationwide epidemiological surveillance studies of Staphylococcus aureus infections. Journal of Clinical Microbiology, 45, 127-133.

Hartstein, A.I. \& Mulligan, M.E. (1986). Methicillinresistant Staphylococcus aureus. In: Glen Mayhall $C$, ed. Hospital epidemiology and infection control. Maryland: Williams and Wilkins, 290-306.

Hashimoto, H., Inoue, M. \& Hayashi, I. (1994). A survey of Staphylococcus aureus for typing and drugresistance in various areas of Japan during 1992 and 1993 [Japanese]. Japanese Journal of Antibiotics, 47, 618-626.
Jevons, M.P. (1961). Celbenin-resistant staphylococci. British Medical Journal, 1, 124-125.

Koneman, E.W., Allen, S.D., Janda, W.M., Schreckenberger, P.C., Winn, W.C., Procop, G. \& Woods, G. (2005). Color Atlas and Textbook of Diagnostic Microbiology. Sixth edition. Philadelphia: Lippincott Co., 700-711.

Montesinos, I., Salido, E. \& Delgado, T. (2002). Epidemiologic genotyping of methicillin-resistant Staphylococcus aureus by pulsed-field gel electrophoresis at a university hospital and comparison with antibiotyping and protein $\mathrm{A}$ and coagulase gene polymorphisms. Journal of Clinical Microbiology, 40, 2119-2125.

Murray, P.R. (2003). Manual of clinical microbiology, 8 th ed. ASM Press, Washington, DC.

Nagase, N., Shimizu, A. \& Kawano, J. (2002). Characterization of Staphylococcus aureus strains isolated from bovine mastitis in Japan. Journal of Veterinary and Medical Science, 64, 1169-1172.

Scherrer, D., Corti, S. \& Muehlherr, J.E. (2004). Phenotypic and genotypic characteristics of Staphylococcus aureus isolates from raw bulk-tank milk samples of goats and sheep. Veterinary Microbiology, 101, 101-107.

Schmitz, F.J. \& Jones, M.E. (1997). Antibiotics for treatment of infections caused by MRSA and elimination of MRSA carriage. What are the choices? International Journal of Antimicrobial Agents, 9, 1-19.

Su, C., Herbelin, C. \& Frieze, N. (1999). Coagulase gene polymorphism of Staphylococcus aureus isolates from dairy cattle in different geographical areas. Epidemiology and Infection, 122, 329-336.

Zhang, K., Sarling, J. \& Chow, B.L. (2004). New quadriplex PCR assay for detection of methicillin resistance and simultaneous discrimination of $S$. aureus from coagulase-negative staphylococci. Journal of Clinical Microbiology, 42, 4947-4955.

\section{Corresponding author's:}

Prof. Dr. Alper ÇİFTCİ

Ondokuz Mayıs Üniversitesi, Veteriner Fakültesi, Veterinerlik Mikrobiyolojisi AbD, Samsun, Türkiye.

\E-mail: aciftci@omu.edu.tr

ORCID: https://orcid.org/0000-0002-4913-6035 